T. Zhuravlova,

$\mathrm{PhD}$ in Economics, Associate Professor, Head of Finance, Banking

and Insurance Department, Odessa I.I. Mechnikov National University

\title{
BANK LENDING OF AGRICULTURAL ENTERPRISES
}

\author{
Т. О. Журавльова, \\ к. е. н., доцент, завідувач кафедри фінансів, банківської справи та страхування, \\ Одеський національний університет імені I. I. Мечникова \\ ORCID ID: 0000-0002-4235-1955
}

\section{БАНКІВСЬКЕ КРЕАИТУВАННЯ СІАЬСЬКОГОСПОААРСЬКИХ ПІАПРИЕМСТВ}

The article highlights the features of lending to agricultural enterprises by commercial banks. The agrarian sector occupies an important place in the economy of Ukraine, and the normal functioning of the entire national economy and life of the country depends on agricultural development. The purpose of the article was to determine the role of bank lending to agriculture, the factors of its formation, the rationale for the need to increase agricultural lending and to analyze the factors that impede the development of credit relations. The trends of credit system development and factors that increase the financing efficiency of the agrarian sector are determined. The current state of crediting of the agro-industrial complex by the banking institutions, stimulating its development is analyzed, as well as proposals and recommendations on the further effective financing of enterprises of the agrarian sector of the economy of Ukraine in the current economic conditions. The analysis and research of the tendencies characterizing the state of agriculture made it possible to conclude that bank loans are not able to fully meet the needs of agricultural enterprises for credit resources; mainly bank loans are issued for short and medium term; regulation of credit provision for agricultural enterprises is ineffective and public support is inadequate; unsatisfactory volumes of credit inflows into the agricultural sector due to harsh conditions and high interest rates. Activation of bank lending to agricultural enterprises requires further improvement of the legal framework on bank lending; simplifying the procedure of obtaining a bank loan for agricultural enterprises; renewal and improvement of the mechanism of cheaper loans to agricultural enterprises; applying economic incentives to commercial banks that lend to the agricultural sector of the economy; implementation of new forms of bank lending guarantee; stimulating the development of property insurance, financial and entrepreneurial risks in the agricultural sector; reducing the risk of non-repayment of credit facilities, namely, providing benefits to those agricultural enterprises that have multiple sources of income; more active provision of credit support to agro industrial units that have a full production and marketing cycle.

У статті висвітлено особливості кредитування комерційними банками сільськогосподарських підприємств. Аграрний сектор займає важливе місце в економіці України, а від його розвитку залежить нормальне функціонування всього національного господарства й життя країни. Метою статті стало визначення ролі банківського кредитування сільського господарства, чинників його формування, обгрунтування необхідності підвищення кредитування сільського господарства та аналіз чинників, які перешкоджають розвиткукредитних відносин. Визначено тенденції розвитку системи кредитування та чинники, які підвищують ефективність фінансування 
аграрного сектору. Проаналізовано сучасний стан кредитування галузі АПК з боку банківських установ, стимулювання його розвитку, а також надано пропозиції та рекомендації щодо подальшого ефективного фінансування підприємств аграрного сектору економіки України в сучасних умовах господарювання. Проведений аналіз та дослідження тенденцій, що характеризують стан кредитування АПК дали змогу зробити висновки про те, що банківські кредити неспроможні повною мірою забезпечити потреби сільськогосподарських підприємств у кредитних ресурсах; головним чином банківські кредити видаються на коротко- та середньотермінові періоди; регулювання кредитного забезпечення сільськогосподарських підприємств є малоефективним, а державна підтримка - недостатньою; незадовільні обсяги надходження кредитних ресурсів в аграрну сферу через жорсткі умови та високі відсоткові ставки. Активізація банківського кредитування підприємств АПК потребує подальшого вдосконалення нормативно-правової бази з питань банківського кредитування; спрощення процедури одержання банківського кредитудля аграрних підприємств; відновлення та вдосконалення механізму здешевлення кредитів аграрним підприємствам; застосування економічних стимулів до комерційних банків, які кредитують аграрний сектор економіки; застосовування нових форм гарантування банківського кредитування; стимулювання розвитку страхування майна, фінансових і підприємницьких ризиків в аграрній сфері; зменшення ризиків неповернення кредитних коштів, а саме надання переваг тим сільськогосподарським підприємствам, які мають декілька джерел доходів, тобто займаються диверсифікованою діяльністю; активнішого надання кредитної підтримки агропромисловим формуванням, які мають повний цикл виробництва та збуту продукції.

Key words: credit, crediting, banking system, credit resources, agricultural enterprise.

Ключові слова: кредит, кредитуъання, банківська система, кредитні ресурси, сільськогосподарське підприємство.

\section{INTRODUCTION}

A powerful agricultural sector is a pledge of our own food security, retaining leading positions in world trade, and most importantly, the basis for the development of the Ukrainian village, which is gradually recovering. The share of agricultural production in the GDP of Ukraine in 2018 is $12 \%$. And this figure is constantly increasing. Similarly, the index of foreign exchange earnings attracted by agricultural enterprises is increasing. In 2018 , agricultural enterprises accounted for $40 \%$ of foreign exchange earnings.

Thus, the agrarian sector occupies an important place in the economy of Ukraine, and on its development depends the normal functioning of the entire national economy and life of the country. Given the interest of many countries of the world and the European Union, in particular in the active participation of domestic suppliers of agricultural products in the global food market, the agricultural sector should become the most powerful engine of development of the national economy, which is possible in the presence of financial opportunities for agricultural producers. In agricultural enterprises, there is a lack of funds that would be used for the purchase of plant and animal protection products, seeds, fertilizers, fuel, and the purchase of new equipment, as existing equipment is already worn out and outdated. In such circumstances, only lending to agricultural enterprises can solve the problem related to the specificity of agricultural production as a subject of lending. Therefore, credit resources play a crucial role in the development of agriculture. This is due to the seasonal gap between investment and cash flow and the continuity of the playback process. In this case, the seasonality of production in agriculture in the normal reproduction process requires the provision of a rational relationship between own and borrowed funds. This, in turn, necessitates the need to evaluate trends in agricultural lending, which confirms the relevance of the study.

\section{ANALYSIS OF RECENT RESEARCH}

In the economic literature of recent years much attention has been paid to the problem of crediting agricultural enterprises in Ukraine by such scientists as M.Ya. Demyanenko, V.M. Alexeychuk, P.A. Layko, P.T. Sabluk, V.O. Palamarchuk, M.I. Savluk, T.T. Kovalchuk and others.

Thus, Aleskerova, Fedoryshyna, Koval (2018) argue that the agricultural business needs significant support for the process of resource recovery. The objective necessity of applying a loan for reproduction of fixed assets is conditioned by the specific nature of the 


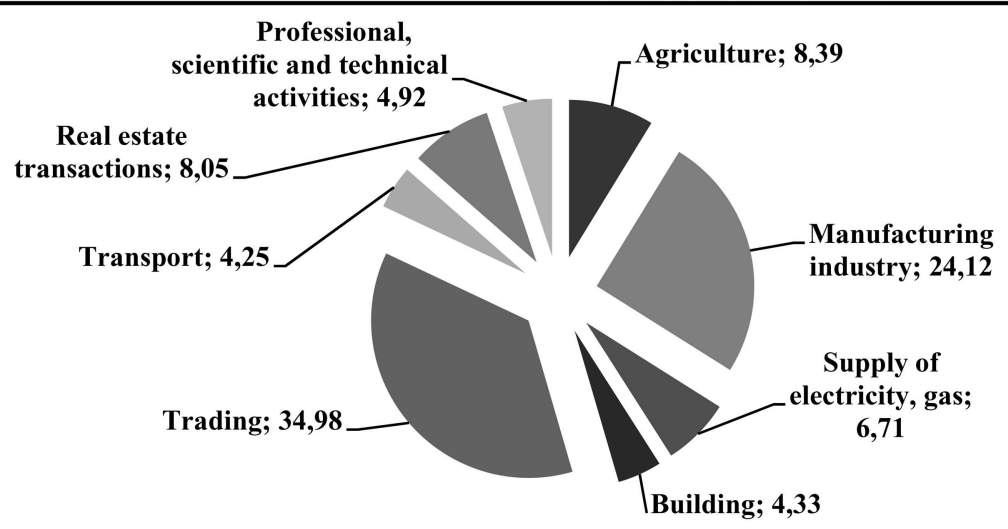

Fig. 1. Bank credits by type of economic activity, $\%$, as of end of August 2019

seasonal nature of the process of production in agriculture. Klimontowicz (2019) believes that banks are crucial to financing the economy, regulating payments and providing products that allow other businesses to develop their financial and market resilience. The stability of the banking market affects the stability of the financial system, sustainable economic growth, as well as the economy as a whole.

Zavadska (2018) determines that a special task for the development of the modern economy of Ukraine is to increase the role of banks in shaping the necessary resources for the implementation of innovation policy. Ivanov, Hromenko, Rodina (2018) argue that it is impossible to ensure the active development of the economy, to strengthen the democratic foundations of Ukraine and to raise the standard of living of the population without the effective functioning of the credit and financial mechanism, which is a component of the banking system.

Rogach, Vdovenko, Polishchuk (2019) write that the current system of financial support for agriculture in Ukraine is on a vector of formation and adaptation to the conditions of the European Union. The EU's financial support policy for agriculture in the European Union ensures high results in agricultural production, economic and social processes and the promotion of agriculture. Rostetska, Naumkina (2019) develop the theory and practice of cooperation of Central European countries in the context of modern European integration processes, which is important for the development and implementation of foreign and domestic policy strategies in European countries and Ukraine.

Given their significant contribution to the research of agricultural lending problems, the challenges of today require the formation of new indicators and approaches to finding and selecting a variety of lending options for agricultural enterprises and defining the horizons of quality lending mechanism. These facts determine the significance, relevance and importance of the chosen research topic.

\section{HIGHLIGHTING PREVIOUSLY UNRESOLVED PARTS OF A COMMON PROBLEM}

The research of scientists who dealt with the problem of lending to agricultural enterprises addresses a wide range of issues regarding the relationship of agricultural enterprises with commercial banks, the creation of specialized financial infrastructure focused on servicing the agricultural sector, improving the efficiency of use of credit resources and more. These scientific achievements have become a fundamental basis for solving the most pressing issues of financial and credit support for agricultural production.

\section{FORMULATING THE ARTICLE GOALS}

The magnitude of the problematic issues requires further refinement of banks' credit policies, which would help to create economic conditions for the efficient functioning of agricultural enterprises.

The purpose of the article is to determine the role of bank lending to agriculture, the factors of its formation, the rationale for the need to increase agricultural lending and to analyze the factors that impede the development of credit relations.

\section{RESULTS}

The considerable need for working capital, due to the lack of own funds, transforms the loan into a significant source of financial resources and necessitates the search for ways of credit security. However, obtaining loans for agricultural enterprises remains problematic. To a large extent, the problems of crediting are due to: decrease in the amount of state support for agriculture; the inaccessibility of credit resources to agricultural enterprises at high interest rates; ignoring the crediting of the seasonality of works. With the further development of market relations, the dependence of agriculture on the financial and credit system has increased and continues to grow even more.

All areas of partnership between a business and a commercial bank, including in the field of lending, are governed by bilateral agreements. They record the conditions under which the bank maintains customer accounts, lending, non-cash payments on their warrants, cash services, including the conduct of collection and transportation of banknotes, trust transactions, advisory services related to banking, etc.

The legislation of Ukraine stipulates that each enterprise has the right to open a current account with one or more commercial banks of its choice. The current account is used to carry out all settlement and cash operations (payments of the enterprise to its suppliers, to the state budget, crediting of the funds coming to the 
enterprise from the buyers, issuing cash for payment of salaries to the employees and employees of the enterprise, etc.). As for other banking operations, including opening deposit accounts, obtaining and repaying loans, the company has the right to enter into partnership not only with banks in which its current accounts are opened, but also with other banks. This creates conditions for competition between banks, for the fight for clientele, which facilitates the establishment of market relations and improvement of banking in the country.

Credit resources of commercial banks, at the expense of which they are able to lend to enterprises, are formed at the expense of their authorized capital and borrowed funds - balances of cash in current and other accounts of their clients, deposits, as well as credits of the National Bank, interbank loans of other commercial banks.

The main document governing the credit relationship between the company and the bank is a loan agreement. The company and the bank independently develop the forms of their contractual relations, so credit agreements can be drawn up either once a year or on a case-by-case basis, and loans can be given once or according to an open line of credit.

In order to guarantee repayment of loans, commercial banks are constantly examining the creditworthiness of borrowers and the material security of loans in the process of corporate lending (creditworthiness is the ability of a borrower to make payments on all types of its economic obligations in a timely manner). The main criteria for assessing the creditworthiness of an enterprise, which are taken into account by banks, are:

- the percentage of the borrower's own funds (at least $50 \%$ );

- reputation of the borrower, including the criterion of timely repayment of loans received earlier;

- security of production of the enterprise with sale, etc.

Banking lending to agriculture should be understood as economic relations regarding providing agricultural enterprises with a priority source of financing on terms of return, payment, security, timeliness and purposeful use, accompanied by specific features inherent in agricultural enterprises.

Credit relations of agricultural enterprises with commercial banks - economic relations arising in the course of conducting commercial transactions by commercial banks aimed at providing agricultural enterprises with credit resources on terms that take into account the basic principles of lending and objective requirements of the industry regarding the validity of the term, volume, value, timeliness of its receipt to the borrower, the order of repayment and interest payment for its use. Figure 1 shows the structure of bank loans by type of economic activity, as of the end of August 2019.

Credit resources play a crucial role in the development of agriculture. This is due to the seasonal gap between investment and cash flow and the continuity of the playback process. The considerable need for working capital, due to the lack of own funds, transforms the loan into a significant source of financial resources and necessitates the search for ways of credit security. However, obtaining loans for agricultural enterprises remains problematic. To a large extent, the problems of crediting are due to: decrease in the amount of state support for agriculture; the unavailability of credit resources for agricultural enterprises at high interest rates; ignoring the crediting of the seasonality of works. It should be noted that the nature and forms of APC bank lending are determined by the specific features inherent in the cross-sectoral complex.

The current state of agriculture is determined by the following factors:

- lack of a well-grounded concept of development of the agricultural sector of the country and imperfect legislative base;

- significant lag of agro-industrial production from other sectors of the economy by the level of stockpiling of labor;

- outdated technologies for the production and use of morally and physically worn equipment, which leads to significant losses of the crop: the industry is provided with machinery only $60 \%$ of the need, in addition, more than $80 \%$ of the agricultural machinery fleet has already worked out its depreciation period, resulting in about $12-15 \%$ of cereals remain in the fields annually;

- significant payments to the budget and especially extrabudgetary funds lead to a decrease in profitability of agricultural enterprises;

- high riskiness of the industry with relatively low level of profitability compared to other sectors of the economy;

- slow turnover of funds at the production stage due to the long technological process in agriculture and animal husbandry;

- lack of appropriate mechanisms for regulating the agricultural market and maintaining prices for the main types of agricultural products;

- lack of effective internal market protection mechanisms and measures to create favorable conditions for agricultural exports;

- gradual and uneven accumulation of costs, which at the end of the production cycle is completed by the return of funds in the form of revenue from the sale of products, so seasonal costs to agricultural producers it is better to recover from the loan than at the expense of own funds, since the latter requires the removal of significant amounts is to a degree determined by the size of the purchase prices and the profit received;

- increase in accounts receivable for agricultural products, which requires improvement of the system of payments and additional financial support to the industry;

- occurrence of time lags in the need for loans and the urgent possibility of their repayment.

It should be noted that the features of agricultural production significantly affect the organization of credit relations. Identifying and taking into account these features will create specific conditions for lending, which, in turn, will strengthen the financial condition of agricultural enterprises and will increase the volume of products produced by them. In our opinion, the most determining factors influencing the organization of credit relations in the agar sector of the economy today are the use of land by agricultural enterprises as the main means of 


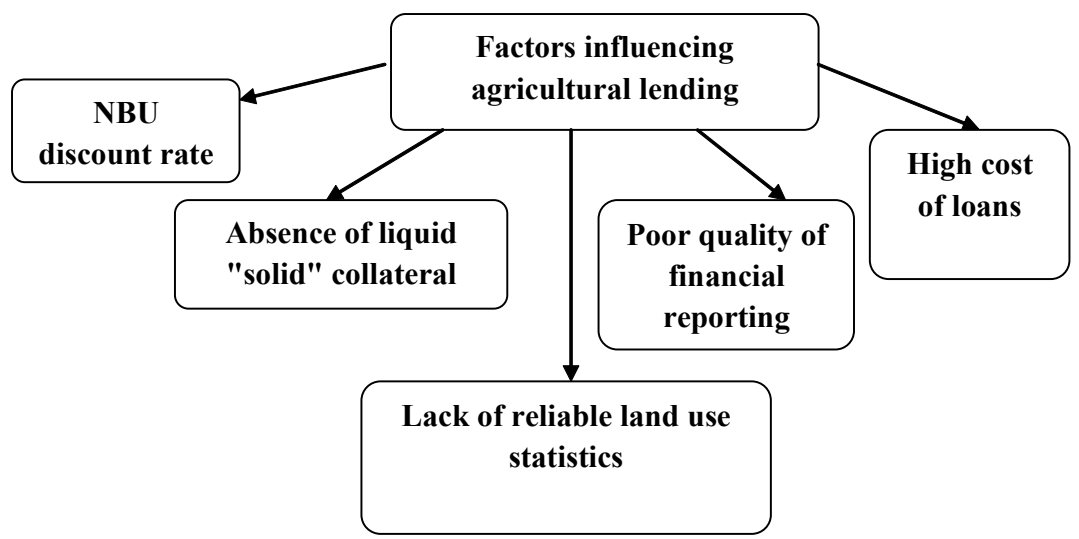

Fig. 2. Factors affecting the credit status of agriculture

production, significant deterioration of fixed assets, low profitability and loss of agricultural enterprises, as well as lack of liquidity.

Obstacles to increasing agricultural credit are the lack of traditions of the agricultural sector in market conditions, low culture of work of borrowers with loans and insufficient level of knowledge of the borrowers about the market of credit services, which are more relevant to small farms, high dependence of creditworthiness on such unforeseen factors as unforeseen factors. high depreciation of fixed assets, non-diversification of business (for example, if the economy is engaged only in crop production, then adverse weather conditions). Days conditions in this case jeopardize the result of the activity as a whole and including the repayment of the loan).

Banking institutions prefer financing to large agricultural producers, which is explained by the following reasons:

- availability of organized financial reporting from large companies;

- availability of sufficient and up-to-date credit security;

- diversification of areas of activity of large enterprises, which can compensate for possible losses in one of the areas of activity;

- ignorance and lack of technologies for conducting financial analysis of agricultural enterprises;

- insufficiency of specialists to work with small agricultural enterprises (banks benefit from large loans with relatively lower labor costs) and so on.

Thus, small and medium-sized farmers in Ukraine have insufficient access to bank lending. The most typical trends in agricultural lending in 2017-2019 are:

1) bank lending in the general financing structure of agricultural producers competed with commodity loans; those customers who were unable to negotiate with the banks received deferrals from the suppliers of goods by financing the sowing;

2) a rather limited range of banks, mainly banks with foreign capital, are engaged in active financing of the agricultural industry;

3) banks have stepped up to conclude and launch partnership programs with suppliers of plant protection products, fertilizers, seeds;

Today, Ukrainian banks have a wide arsenal of financial instruments for agrarian business, namely financing of working and investment capital in the form of credit, credit line, overdraft, trade financing (guarantees, letters of credit, aval), leasing, pre-export financing.

In 2018, most special financing proposals addressed to agricultural companies feature preferential terms for working capital financing (term loans, credit lines) and / or affiliate programs for the purchase of agricultural machinery and other products. In addition, every second or third bank has targeted offers to farmers for oval bills or financing an investment project (often it is an elementary purchase of agricultural machinery). Despite the variety of banking products and programs, the lending rates of banks to agricultural sector entities are small, with several hundred million hryvnias at those banks that have published relevant information. Thus, when lending to banks in the real sector of the economy, it is possible to distinguish general constraints that are relevant to all areas of lending, and specific, which are characteristic only of agricultural credit. But the development of the agricultural sector should not be limited to bank lending.

That is why every year the State Budget Law defines the types of state targeted programs to support agribusiness enterprises and the amount of their expenditures. High cost of loans Banks place value of resources and basic level of risk in the cost of loans. It is known that deposit rates in Ukraine are some of the highest in Europe, so it is a rather expensive resource for banks. The lack of legislation on the protection of creditors, leads to high credit risk, which also has a negative impact on the size of the loan rate.

Farmers who need loans often do not have the full amount of collateral to take out a loan under the state program, and banks are not interested in working with farmers who have less than 500 hectares in their majority ownership ( $84 \%$ of operating farms have tillage up to 500 ha).

For a more detailed explanation of the topic of the study, consider a standard model of unfavorable choice (AS), characterized by a competitive lending market, with (1) producers endowed with one asset each and who need to borrow to finance their business; and (2) competing lenders who face potential costs equal to zero and produce zero profit in equilibrium.

Manufacturing companies are of two types: risky (with high probability of bankruptcy) and safe (with low 
probability of bankruptcy). In a unified equilibrium, where all businesses are funded, secure enterprises will build risk subsidies. Therefore, they could benefit from credit through a particular tool. This instrument can be a pledge.

There are two identical credit markets, one acting on condition 1 and the other on condition 2, where:

1. Subject to condition 2, no assets shall be released from liquidation in the event of bankruptcy.

2. Subject to condition 1, all unsecured assets shall be released in the event of bankruptcy.

Let's consider first case 1. In the event of bankruptcy, the assets of the enterprises are liquidated anyway; regardless of whether, were they posted as collateral or not. Therefore, the placement of collateral does not play any role as a tool. Neither the cost of the loan nor the access to the loan can affect the decision to place a pledge. Accordingly, in Situation 1, the prevailing equilibrium has to be combined equilibrium where it is financial, an exchange occurs, the same contract applies to all enterprises, regardless of whether they place a pledge. Let us now consider the situation 2. In the event of bankruptcy, the assets of the enterprises will be liquidated only if they were placed as collateral. Therefore, in the event of bankruptcy, the company that placed the pledge would suffer more losses than the enterprise that did not place it. Placement of collateral now has potential costs. Most importantly, such an alternative cost is expected to depend on the activity. Risky businesses are more likely to fail than secure businesses, so their collateral placement costs more than secure businesses.

A credit market model is provided to fully analyze the role of collateral, loan cost, and access to credit when AS is a source of asymmetric information. The theoretical predictions for the AS case are then used to identify the role of collateral.

It is considered a competitive market populated by a large number of enterprises $(E)$ and a large number of creditors $(L)$. The set of enterprises $(E)$ and creditors $(L)$ are indexed by $e=1, \ldots ., E$ and $I=1, \ldots ., L$ respectively. Both businesses and lenders are risk-averse. Lenders are endowed with one unit of financial resources each, and will have an additional cost of capital, $r>0$. Each entrepreneur, $\mathrm{e}$, is endowed with the opportunity to invest a fixed amount and the amount to be pledged we $[0, w]$.

Without losing its generality, $L / E>1$ is installed, so that financial resources are abundant. For any given asset level, w, is defined by Ew E, a subset of enterprises with resources $w$, and $E(w)=|E w|$ accordingly the number of entrepreneurs. The investments last for one period and bring the total $R>0$ with probability $p$ and 0 otherwise, when $p$ is a function of the type of enterprise, $q$.

Share $\lambda$ of type $H$ (safe) and share $1-\lambda-$ type $L$ (risky). We assume pLR $>(1+r)$, which means that both safe and risky businesses are worth the funding. The previous type of enterprise is private information as well as information about available assets of the enterprise.

Finally, it is assumed that the value of the asset value $w$ for the lender is $\beta w$, with $\beta<1$. Therefore, the liquidation of the assets of the company to pay for a bank loan is inefficient.

\section{CONCLUSIONS}

Therefore, credit resources play a crucial role in agricultural development The banking system and the state do not play a proper role today in providing agricultural enterprises with financial resources. The high cost of credit, the lack of adequate security, and the lack of creditworthiness of most farms hinder the development of effective relationships between commercial banks and agricultural producers.

The analysis and research of the tendencies characterizing the state of agriculture of the agricultural sector made it possible to conclude that bank loans are not able to fully meet the needs of agricultural enterprises for credit resources; mainly bank loans are issued for short and medium term; regulation of credit provision for agricultural enterprises is ineffective and public support is inadequate; unsatisfactory volumes of credit inflows into the agricultural sector due to harsh conditions and high interest rates. Activation of bank lending to agricultural enterprises requires further improvement of the legal framework on bank lending; simplifying the procedure of obtaining a bank loan for agricultural enterprises; renewal and improvement of the mechanism of cheaper loans to agricultural enterprises; applying economic incentives to commercial banks that lend to the agricultural sector of the economy; implementation of new forms of bank lending guarantee; stimulating the development of property insurance, financial and entrepreneurial risks in the agricultural sector; reducing the risk of non-repayment of credit facilities, namely, providing benefits to those agricultural enterprises that have multiple sources of income; more active provision of credit support to agro industrial units that have a full production and marketing cycle.

In view of the above, as well as on the basis of generalization of the domestic and world experience of highly efficient agricultural credit markets in order to solve the investigated problems and eliminate the credit deficit in the subjects of agro industrial complex, we consider it advisable to carry out the following measures:

1. Provide pre-emptive specialization of banks in a limited range of financial services and adapt them to the services of agribusiness entities (which will greatly minimize the associated risks and adapt the loans provided to the particularities of the industry).

2. Strengthen the role of the mortgage of the land (which is convenient when providing a loan. It is impossible to provide for the expected breeding of livestock and material values of agricultural production).

3. Increase the importance of analyzing financial statements and the market when deciding on a loan.

4. To increase the level of risk management and risk insurance in lending to agricultural enterprises.

5. Ensure the extension of credit agreements or deferral of payments for stagnation period - up to 1 year (which will allow farmers to sell products at better prices).

These measures will overcome the temporary difficulties of agricultural development and will ensure the achievement of significant competitive advantages of the products of this industry, strengthen not only the food selfsufficiency of the country, but also intensify the loading of related industries. 
Література:

1. Вовчак О.Д. Стан і проблеми розвитку банківського кредитування сільськогосподарських підприємств України / Вовчак О.Д., Гальків Л.І., Демчишин М.Я. // Фінансово-кредитна діяльність: проблеми теорії та практики. - 2018. - Вип. 3 (26). - С. 30-37.

2. Державний сайт статистики України. URL: http:/ /www.ukrstat.gov.ua/

3. Концепція Державної цільової програми розвитку аграрного сектору економіки на період до 2020 р. / / Oфріційний сайт Міністерства аграрної політики та продовольства.URL: http://minagro.gov.ua/apk?nid=16822

4. Фінансова дієта: чим банки закінчують цей рік i що готують для АПК в наступному. URL: http:/ / directinvest.com.ua/ru/2017/12/20/finansova-diyeta-chimbanki-zakinchuyut-cej-rik-i-shho-gotuyut-dlya-apk-unastupnomu-ch-2

5. Коробкова О.В. Ефективне агрофрінансування проблеми та їх вирішення. URL: https://agrianalytica.com/uk/service/agrarian/credit

6. Про державний бюджет України на 2018 рік: Закон України від 7 грудня 2017 р. № 2246-VIII. URL: http:/ /search.ligazakon.ua/I_doc2.nsf/link1/T172246.html

7. Матеріали офріційного сайту Національного банку України [Електронний ресурс]. - Режим доступу: http:// www.bank.gov.ua

8. Міністерство аграрної політики та продовольства України [Електронний ресурс]. - Режим доступу: https://dotacii2019.minagro.gov.ua/

9. Aleskerova Yu., Fedoryshyna L., Koval N. 2018 Features of loan security for the reproduction of fixed assets for agricultural purposes. Baltic Journal of Economic Studies, Vol. 4, No. 4, 2018. pp. 1-5. DOl: https:// doi.org/10.30525/2256-0742/2018-4-4-1-5

10. Klimontowicz M., 2019. The role of banks innovativeness in building sustainable market efficiency: the case of Poland, Entrepreneurship and Sustainability Issues 7(1): 525-539. http://doi.org/10.9770/ jesi.2019.7.1(37)

11. Zavadska D. 2018. Determining the role of banks in the financing of innovative development processes of the economy, Baltic Journal of Economic Studies, Vol. 4, No. 3, pp. 68-73. DOl: https://doi.org/10.30525/22560742/2018-4-3-68-73

12. Ivanov S., Hromenko Yu., Rodina V. 2018. Problems of banking legal relationships, Baltic Journal of Economic Studies, Vol. 4, No. 5, pp. 94-99 DOl: https://doi.org/ 10.30525/2256-0742/2018-4-5-94-99

13. Rogach S., Vdovenko L., Polishchuk O. 2019, Agriculture of Ukraine under the joint policy of the European Union, Baltic Journal of Economic Studies, Vol. 5, No. 3, pp. 178-183 DOI: https://doi.org/10.30525/22560742/2019-5-3-178-183

14. Rostetska S., Naumkina S. 2019, Paradigms of European integration processes in the EU, visegrad group, and Ukraine, Baltic Journal of Economic Studies. Vol. 5, No. 3, pp. 184-192. DOI: https://doi.org/10.30525/ 2256-0742/2019-5-3-184-192

\section{References:}

1. Vovchak, A.D. Galkiv, L.I. and Demchishin, M. Ya. (2018), "State and problems of development of bank crediting of agricultural enterprises of Ukraine", Financialcredit activity: problems of theory and practice, vol. 3 (26), pp. $30-37$.

2. State Statistics Service of Ukraine (2019), available at: http://www.ukrstat.gov.ua/ (Accessed 10 Nov 2019).

3. Official Website of the Ministry of Agrarian Policy and Food (2016), "Concept of the State Target Program for the Development of the Agricultural Sector for the Economy until 2020", available at: http:/ /minagro.gov.ua/apk?nid=16822 (Accessed 10 Nov 2019).

4. Direct investment in business (2017), "The financial diet: how banks finish this year and prepare for AIC in the next", available at: http://directinvest.com.ua/en/ 2017/12/20/finansova-diyeta-chim-bank-zakinchuyutcej-rik-i-shho-gotuyut-dlya-apk-in-in-progress-ch- 2 (Accessed 10 Nov 2019).

5. Korobkova, O.V. (2018), "Effective agro-financing - problems and solutions", available at: https:// agrianalytica.com/en/service/agrarian/credit (Accessed 10 Nov 2019).

6. Verkhovna Rada of Ukraine (2017), The Law of Ukraine "On the State Budget of Ukraine for 2018", available at: //search.ligazakon.ua/I_doc2.nsf/link1/ T172246.html (Accessed 10 Nov 2019).

7. Materials of the official site of the National Bank of Ukraine (2019), available at: www.bank.gov.ua (Accessed 10 Nov 2019).

8. Ministry of Agrarian Policy and Food of Ukraine (2019), available at: https://dotacii2019.minagro.gov.ua/ (Accessed 10 Nov 2019).

9. Aleskerova, Yu. Fedoryshyna, L. and Koval, N. (2018), "Features of loan security for the reproduction of fixed assets for agricultural purposes", Baltic Journal of Economic Studies, vol. 4, no. 4, pp. 1-5. DOl: https:// doi.org/10.30525/2256-0742/2018-4-4-1-5

10. Klimontowicz, M. (2019), "The role of banks' innovation in building sustainable market efficiency: the case of Poland", Entrepreneurship and Sustainability, vol. 7 (1), pp. 525-539. http://doi.org/10.9770/ jesi.2019.7.1(37).

11. Zavadska, D. (2018), "Determining the role of banks in the financing of innovative development processes of the economy", Baltic Journal of Economic Studies, Vol. 4, No. 3, pp. 68-73. DOl: https://doi.org/ 10.30525/2256-0742/2018-4-3-68-73

12. Ivanov, S. Hromenko, Yu. and Rodina, V. (2018), "Problems of banking legal relationships, Baltic Journal of Economic Studies", Vol. 4, No. 5, pp. 94-99. DOI: https:/ /doi.org/10.30525/2256-0742/2018-4-5-94-99.

13. Rogach, S. Vdovenko, L. and Polishchuk, O. (2019), "Agriculture of Ukraine under the common policy of the European Union", Baltic Journal of Economic Studies, Vol. 5, No. 3. pp. 178-183. DOI: https://doi.org/ 10.30525/2256-0742/2019-5-3-178-183.

14. Rostetska, S. and Naumkina, S. (2019), "Paradigms of European integration processes in the EU, multigrade group, and Ukraine", Baltic Journal of Economic Studies, vol. 5, No. 3, pp. 184-192. DOI: https://doi.org/ 10.30525/2256-0742/2019-5-3-184-192.

Стаття надійшла до редакцї 17.11.2019 p. 